\title{
Tourism competitiveness and the well-being of residents: a debate on registered and non-registered accommodation establishments
}

\author{
José Francisco Perles-Ribes ${ }^{1 *}$, Ana Belén Ramón-Rodríguez ${ }^{2}$, \\ Luis Moreno-Izquierdo ${ }^{3}$ and María Jesús Such-Devesa ${ }^{4}$
}

\footnotetext{
${ }^{1}$ Department of Applied Economic Analysis, Faculty of Economics and Business Sciences, University of Alicante, Campus San Vicente del Raspeig, 0308o Alicante, Spain, Tel: +34 9659036 og. E-mail: jose.perles@ua.es

2 Department of Applied Economic Analysis, Faculty of Economics and Business Sciences, University of Alicante. E-mail: anar@ua.es

3 Department of Applied Economic Analysis, Faculty of Economics and Business Sciences, University of Alicante. E-mail: luis.moreno@ua.es

4 Department of Economics, Faculty of economics, business and tourism, University of Alcalá. E-mail: mjesus.such@uah.es

* Corresponding author
}

\begin{abstract}
The literature on the competitiveness of tourist destinations establishes as its ultimate objective the well-being of the resident population. In Spain, the principal tourism product (sun and beach) has given rise to two basic types of destinations - those where there is a clear predominance of registered accommodation (mainly hotels) and those that are characterised by a supply largely made up of rental apartments and housing (non-registered, or sometimes known as the residential or second home model). The debate on the issue has been focusing on the different economic, social, cultural or environmental impacts that the two tourism models have on the territory. This article explores the economic aspect of the debate, comparing the differences existing in terms of income and employment in a pool of coastal destinations in the Region of Valencia, one of the leading tourism regions of the sun and beach tourism product in Spain and Europe. This comparison is done by way of Null Hypothesis Significance Testing and regression analysis. The results obtained indicate the neutrality of the composition of the accommodation supply on income and employment of destinations.
\end{abstract}

Keywords: competitiveness, well-being, accommodation supply, economic impact, Spain

Citation: Perles-Ribes, J. F., Ramón-Rodríguez, A.B., Moreno-Izquierdo, L and Such-Devesa, M. J. (2020). Tourism competitiveness and the well-being of residents: a debate on registered and non-registered accommodation establishments. European Journal of Tourism Research 24, 2406.

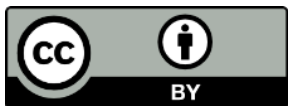




\section{Introduction}

The most common theories of tourism competitiveness, those of Dwyer \& Kim (2003) and of Ritchie \& Crouch (2003), establish the well-being of the resident population as a basic premise of the success of the destinations, which should theoretically adapt their policies to maximise their comparative advantages but without going beyond a limit which would clearly detriment the quality of life (QOL) of the inhabitants.

In Spain, and specifically in one of its leading tourism products (sun and beach), there are two basic types of destination: those in which there is a clear predominance of registered accommodation - mainly hotels - and those characterised by a supply largely made up of apartments and second homes for potential tourist use, many of which are not registered. These two tourism models have given rise to a debate about the different economic, social, cultural or environmental impacts that they generate.

This matter is addressed in this article, which analyses the differences in terms of income and employment in a pool of coastal destinations in the Region of Valencia. Specifically, this article seeks to test, for a group of coastal destinations, the differences in terms of the economic impact on the residents according to the type of tourist accommodation supply. Therefore, it seeks to confirm or refute the recommendation of one type of supply or another based on the well-being of the inhabitants.

If the evidence points to better economic results of hotel destinations, it will be proved that this option is the best in terms of satisfying the well-being of the citizens as these types of destination are also better than residential destinations in terms of sustainability issues. However, if the residential destinations have a greater economic impact, there may be doubts as to whether this difference in well-being criteria is sufficient to compensate the wear suffered in terms of sustainability. Therefore, it is the subject of a continuous debate on the different economic, social, cultural or environmental impacts that they generate, not only within the academic field.

The research topic is timely and relevant and this article complements a dynamic line of research in which residents are understood as being an active part of the tourist community; fundamental actors who facilitate and suffer its development, particularly with the new collaborative supply models and the problem of over-tourism (Cardoso \& Silva, 2018; Postma \& Schmuecker, 2017; Brida, Riaño, Such-Devesa \& Zapata-Aguirre, 2012). While previous articles, such as García \& Servera (2003) or Obrador (2017) study the exploitation of water resources and the sustainability of Mediterranean destinations to address the impact of tourism development on residents and their acceptance of it, this article directly addresses the issue examining the economic factors and, more specifically the levels of income and employment existing in the destinations generated by the different types of tourism development.

The paper is structured as follows. Section 2 reviews the previous literature and explains the basic facts of the residential and holiday tourism in Spain. Section 3 explains the data, and the methodology. Section 3 performs the exploratory data analysis and basic statistical inference and the econometric analysis using Ordinary Least Square (OLS) regression. Finally, section 4 and 5 discuss the main findings and the limitations of the study.

\section{Literature review}

Competitiveness and well-being in tourism destinations: a literature review

Although the relationship between the competitiveness of the destinations and the quality of life of their residents is fairly obvious, the scientific literature on the two topics has, until very recently, taken parallel and independent paths. With respect to the quality of life of the residents of tourism 
destinations and its determinants in different parts of the world, the literature reveals that while there are numerous and disparate interpretations of the terms QOL or well-being (WB) (Filep and Deery, 2010), there is a general consensus on its causes. In this way, authors such as Sirakaya, Teye \& Sönmez (2002), Aref (2011), Nawijn and Mitas (2012), Almeida-García, Peláez-Fernández, Balbuena-Vazquez, and Cortes-Macias (2016) or Liang and Hui (2016) among others, from an applied perspective, have shown that the improvements in economic factors (increased employment, higher incomes, improved infrastructures) are associated with higher levels of quality of life or well-being while problems in economic, social and environmental aspects related to a lack of sustainability, the loss of identity and an excess of tourists is associated to lower levels of satisfaction among the residents of the tourist destinations.

In light of this evidence, an explanatory synthetic model of the quality of life or well-being of the residents of tourist destinations is determined as a function of the direct or indirect economic benefits obtained by the residents, and the perception of the socio-cultural impact and that of sustainability of the destination overall. In this model, while elements such as employment or wealth would help to improve the well-being of the residents, other elements related to climate change or the rental of tourist apartments would be detrimental to it if they were not adequately compensated.

Focusing on competitiveness and its determinants, the literature reveals that these economic, social and environmental aspects that affect the quality of life of the residents are, in turn, related to the competitiveness of the destinations and their sustainability (Modica \& Uysal, 2016). Not only is the quality of life of the residents the ultimate objective of competitiveness, as already mentioned, but these economic, social and environmental aspects also shape the multidimensionality of the concept of tourism competitiveness (Spence \& Hazard, 1988).

For this reason, the tourism strategies aimed at promoting the competitiveness of destinations imply optimising economic performance but in a way that is compatible with the lowest possible social and environmental impact, which essentially is the same as increasing the well-being of the residents of the tourist destinations.

Typology of accommodation, tourism competitiveness and residents' well-being: towards a conceptual framework.

Viewed through this theoretical lens, this study addresses the relationship between the competitiveness of the destinations and the quality of life of their residents, using a comprehensive approach. Figure 1 schematically describes the conceptual framework of reference.

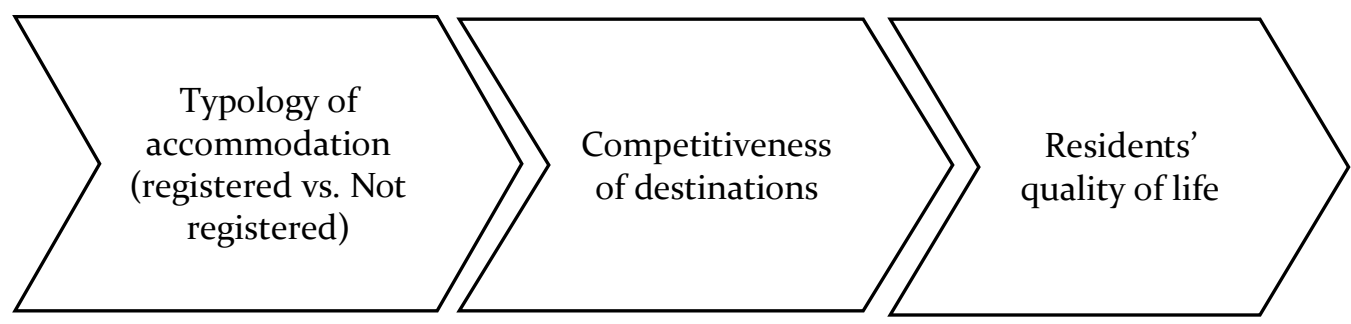

Figure 1. Proposed conceptual framework 
Within this framework, the precursor of the relationship between competitiveness and the quality of life is the type of tourism development prevailing in each destination. It is understood that the predominant type of accommodation supply in a destination (registered or non-registered) conditions its competitiveness, which, in turn, affects the quality of life of its residents.

The data existing for the Spanish case seem to corroborate the plausibility of the proposed framework. Table 1 shows the relationship between the composition of the accommodation supply (second column of the table), the indicators of tourism competitiveness of the regions (first column), the income per capita of the regions (third column) and two synthetic indicators of the quality of life (fourth and fifth columns) generated by different institutions in 15 of the 17 Spanish regions.

The calculation of the Pearson correlation coefficient shows the existence of positive linear associations between a higher presence of regulated supply and the levels of competitiveness of the destinations (o.51). The relationship between the level of competitiveness and income per capita of the region (o.33) also shows a positive association, although to a lesser degree than in the previous case, which is explained by the existence of additional determinants - unrelated to the tourism competitiveness of the region under study - that potentially influence the income levels of its residents.

Finally, and in relation to the debate on the appropriateness of income per capita as a possible indicator of the well-being or quality of life of the inhabitants of a territory, the correlation analysis reveals a positive association between income per capita of the region and the levels of well-being noted by its residents, although the degree varies depending on the choice of specific synthetic index used to reflect the quality of life ( 0.42 in relation to the index calculated by the INE and 0.81 in relation the index calculated by Herrero, Villar \& Soler, 2018).

Spanish hotel-based and residential destinations: an ongoing debate on the effects of each type of accommodation

Turning away from the conceptual map and focusing on the practical aspects, due to the lack of specific data for all of the variables included in the model presented in Figure 1 on a municipal level (level of analysis of this study) the article adopts a simplified version of it to test whether the type of configuration of the accommodation supply (registered or non-registered) of destinations has a real impact on the well-being of the residents, measured through their income per capita.

As explained in the introduction section, to do this, the analysis is based on the two basic types of destination in the sun and sand product: those in which there is a clear predominance of registered accommodation establishments (also called hotel destinations as the predominant accommodation supply in the destinations is hotels) and those characterised by a supply largely made up of apartments and second homes for potential tourist use (also called residential destinations), many of which are not legally registered (Perles-Ribes, Ramón-Rodríguez, Sevilla-Jiménez \& Moreno-Izquierdo, 2018, among others). Thanks to different tour operators, word of mouth and, more recently, platforms such as Airbnb, the supply that is not legally registered has a very high level of activity in Spanish destinations and cannot be considered as being marginal in any way.

In general terms, academics have shown a preference for the registered typology, with a greater presence of hotels in the destinations, due to the higher economic profits and lower environmental impacts (Gartner, 1987; Hall, 2015; Mazón, 2006; Vera \& Ivars, 2003). On an environmental level the empirical evidence seems to generate more or less conclusive results (Morote, Saurí, \& Hernández, 2016; Perles- 
Ribes, Ramón-Rodríguez, Ivars-Baidal \& Such-Devesa, 2018). On an economic level the results are more controversial.

Table 1. Relationship between tourist accommodation, competitiveness and well-being in Spanish regions

\begin{tabular}{|c|c|c|c|c|c|}
\hline Region & $\begin{array}{l}\text { Exceltur } \\
\text { competitiveness } \\
\text { index } 2018 \\
\end{array}$ & $\begin{array}{l}\text { accommodation } \\
\text { supply ratio } \\
\text { (registered/ } \\
\text { non-registered) } \\
\text { index }\end{array}$ & $\begin{array}{l}\text { GDP per } \\
\text { capita } 2018\end{array}$ & $\begin{array}{l}\text { Satisfaction } \\
\text { (well- } \\
\text { being) } \\
\text { index INE } \\
2013 \\
\end{array}$ & $\begin{array}{l}\text { Satisfacción } \\
\text { (weññ- } \\
\text { being) } \\
\text { BBVA-IVIE } \\
2018 \\
\end{array}$ \\
\hline País Vasco & 112.60 & 74.79 & 131.80 & 102.90 & 136.64 \\
\hline Canarias & 111.20 & 455.22 & 81.30 & 100.00 & 54.02 \\
\hline C.Madrid & 109.90 & 82.59 & 135.10 & 101.45 & 130.28 \\
\hline C.Valenciana & 108.60 & 63.37 & 87.60 & 102.90 & 85.79 \\
\hline Cataluña & 108.30 & 94.89 & 119.00 & 102.90 & 104.86 \\
\hline Andalucía & 107.20 & 76.39 & 74.00 & 97.10 & 54.02 \\
\hline Baleares & 106.30 & 450.50 & $103 \cdot 50$ & 105.80 & 101.68 \\
\hline Castilla \& León & 97.00 & $27 \cdot 30$ & 94.40 & 94.20 & 114.39 \\
\hline Galicia & 95.90 & 33.65 & 90.10 & 88.41 & 98.50 \\
\hline Navarra & 95.20 & 68.43 & 123.00 & $104 \cdot 35$ & 133.46 \\
\hline Asturias & 95.00 & $53 \cdot 39$ & $89 \cdot 30$ & 101.45 & 104.86 \\
\hline Murcia & 94.90 & 29.70 & 81.70 & 100.00 & 69.91 \\
\hline Castilla La Mancha & 93.60 & 23.93 & $79 \cdot 90$ & 101.45 & 76.26 \\
\hline Cantabria & 92.80 & 51.07 & 92.10 & 98.55 & $117 \cdot 57$ \\
\hline La Rioja & 91.40 & 33.19 & 103.80 & 101.45 & 136.64 \\
\hline Extremadura & 91.20 & 26.65 & 70.30 & 98.55 & 76.26 \\
\hline Aragón & 91.10 & 54.96 & 110.80 & 101.45 & 104.86 \\
\hline
\end{tabular}

Index numbers Spain = 100. Source: Exceltur (2018b); INE (2018a, b); Herrero, Villar \& Soler, (2018)

Going beyond the academic field and in the case of Spain, Exceltur, an organisation formed by the country's most important tourism companies, also clearly advocates the advantage of the registered accommodation typology based on issues relating to the economic impact on the destinations. These conclusions are draw from the pioneer study on the differences in economic terms between the different types of accommodation supply (registered and non-registered), based on official sources referring to demand (surveys and records of tourist flows, duration of stay and tourist spending by each type of tourist) and some estimates on tourism supply (Exceltur, 2005).

Specifically, in terms of income (the gross value added generated directly and indirectly in the destinations), the study finds a difference of 11 to 1 in the year 2003 ( $€ 13,634$ for each registered place as opposed to $€ 1,287$ for each place in tourist rental accommodation) (Exceltur, 2005:41). With respect to employment, a difference of 9.5 to 1 was found: which increased to 11 to 1 when the indirect and induced effects on other sectors were taken into account (Exceltur, 2005:43).

According to their reports, these differences persist over time. A new study on the topic in the wake of the debate caused by the strong growth experienced by $\mathrm{P}_{2} \mathrm{P}$ property marketing platforms in Spain in recent years places the current difference at a ratio of 5 to 1 in favour of registered places. In other words, 
the economic activity generated from each registered place represents €24,155 as opposed to the €4,932 generated by each tourist rental accommodation place offered (Exceltur, 2015:46). And in terms of employment, it is currently estimated that for every 100 rented property places 8.9 job positions are generated per year, while the same number of places for registered supply translates into 53.3 job positions (Exceltur, 2015:49).

Apart from the studies carried out by Exceltur, a recent study by Perles-Ribes, Ramón-Rodríguez, Sevilla-Jiménez \& Moreno-Izquierdo (2016) confirms the hypothesis of the better economic performance of destinations where there is a predominance of registered accommodation, comparing the behaviour in terms of employment performance of a series of destinations on the Spanish Mediterranean coast, the Balearic Islands and the Canary Islands during the latest economic crisis. In this study, the authors find that during the crisis, residential destinations displayed worse behaviour in terms of job destruction than hotel destinations, with a clearly negative impact on the well-being of the resident population of the destinations. However, another article by Perles-Ribes, Ramón-Rodríguez, Sevilla-Jiménez \& Moreno-Izquierdo (2018) analyses the different economic performance of the same destinations using the existing retail supply in the destinations as a proxy. In this case and contrary to the previous exercise, the findings do not reveal any significant difference between the two types of destination. Therefore, we cannot draw relevant conclusions about the impact on the well-being of the residents. In this sense, the research field is not closed and this disparity in the results justifies studies that address issues such as this one.

Unlike the afore-mentioned studies that analyse the whole of the Spanish Mediterranean area, this study seeks to shed light on the subject by focusing on a specific region of this area (the Region of Valencia), which enables us to isolate the potential effects that the presence of different regions with their own institutions responsible for tourism and different economic social and demographic structures and specialisations can have on the phenomenon.

In the same way and in order to obtain greater precision in the effect under study, this article contemplates a higher number of control variables than the pre-existing studies on the subject. Both aspects, namely a greater territorial precision and a higher number of variables, are the principle novelties of the article.

\section{Methodology and data}

According to the Exceltur position, it would be expected that residents of the predominantly hotel destinations perceive higher levels of income than those in destinations where the predominant accommodation supply is rental properties. This matter is addressed in this article, which analyses the differences in terms of income and employment in a pool of coastal destinations in the Region of Valencia.

With 7.8 million international tourists in 2016 (10.36\% of the Spanish total) and 17.1 million Spanish visitors (9.44\% of all domestic tourism) it constitutes one of Spain's principal tourist regions (INE, 2017a, b). Tourism is the region's principal source of wealth and employment. According to Exceltur (2018a), the tourism activity represents $14.6 \%$ of regional GDP and $15.1 \%$ of employment, being one of the highest in the whole of Spain, only behind the Balearic Islands (44,8\% of regional GDP) and the Canary Islands (35.2\% of regional GDP). Within the region itself, the weight of tourism in the coastal destinations included in the sample under study is much higher as a very high percentage of the total tourism supply of the region is concentrated in these destinations. 
Previous studies, such as Ivars-Baidal, Rodríguez-Sánchez \& Vera-Rebollo (2013), Vera-Rebollo \& IvarsBaidal (2003) or Moreno-Izquierdo Ramón-Rodríguez, Such-Devesa, \& Perles-Ribes (2019) have analysed the heterogeneity of the types of tourism in the Region of Valencia, where there are highly specialised destinations in terms of both registered and non-registered accommodation supply which generate substantial differences in employment, urban planning or the presence of Airbnb, among other issues.

The analysis has been carried out on a sample of 58 sun and sand destinations in the Region of Valencia. For the final analysis, four towns were eliminated from the sample (the provincial capitals of Valencia, Alicante and Castellón, and the town of Elche), as the weight of tourism in their economies is lower than the rest of tourist destinations due to a greater development of urban and industrial activities which could distort the analysis. This sample of destinations belonging to the Region of Valencia seeks to be representative of the coastal destinations in the Mediterranean Area.

In order to identify the type of supply in the destinations, the total beds in hotels and registered apartments in each of the destinations and the percentage of the number of second residences with respect to the total have been taken. These variables form part of the set of variables used in Perles, Ramón \& Sevilla (2011) to identify the type of sun and beach tourist destination in accordance with their supply. Table 2 explains the variables used in the analysis and their source.

Specifically, of the explanatory variables considered in Table 2, the variable of interest is the ratio variable (RATIO), which reflects the accommodation supply composition of each destination. In order to determine more precisely the scope of the effects that a different accommodation composition generates on the income and employment of the destinations, and as found by Perles, Ivars, Ramón \& Vera (2019), the study has been completed with the incorporation of other variables related to the economic and demographic structure of the relevant destinations in this context and the variables that reflect other structural aspects of the tourism tradition and policy in each province.

The demographic and socio-economic variables included are the size of the destination (POPU), the percentage of European Union foreigners (PIMRES) living in the destinations as a reflection of the degree of residentiality (supply largely made up of apartments and second homes for potential tourist use) of destinations, and the economic conjuncture of each destination (UNEM).

The variables that seek to control the territorial effects derived from the existence of tourism brands or other structural elements of the tourism tradition and policy in each province are included in a categorical variable PROVINCE. These reflect other structural features of the territorial subdivision of the Region of Valencia and the promotional efforts of each international tourism board/trademark (Costa Blanca in Alicante, Costa de Azahar in Castellón and Costa de Valencia in Valencia) in the region.

The study methodology comprises two phases. As an exploratory exercise on this dataset, a means comparison of the income and employment variables between the two kinds of destination (registered vs. non-registered) by way of a Null Hypothesis Significance Test using an independent samples t-test has been performed. The assumptions and conditions for the use of this technique were previously checked and confirmed. To this end, the RATIO variable constructed as the division between the total number of registered places in the destinations and the estimated places in properties potentially used for tourism, and dichotomised into two groups (registered vs. non-registered) using the percentile 0.5 as the cut-off point of the distribution of this variable, seeks to estimate the different composition of accommodation supply in each destination. 
Table 2. Variables used for the analysis

\begin{tabular}{|c|c|c|c|c|}
\hline Element & Variable & Definition & $\begin{array}{l}\text { Year of } \\
\text { reference }\end{array}$ & Source \\
\hline \multicolumn{5}{|c|}{ Dependent variables } \\
\hline Income & INCOME & Average disposable income & 2015 & $\begin{array}{l}\text { Spanish central tax } \\
\text { authority }\end{array}$ \\
\hline Employment & EMPLOY & $\begin{array}{l}\text { Total number of people affiliated to } \\
\text { the Social Security system / Total } \\
\text { population of the destination }\end{array}$ & 2015 & Social Security INE \\
\hline \multicolumn{5}{|c|}{ Explanatory variables } \\
\hline \multirow[t]{2}{*}{ Demographics } & POPU & $\begin{array}{l}\text { Number of inhabitants in the } \\
\text { destination }\end{array}$ & 2015 & $\begin{array}{l}\text { INE Municipal } \\
\text { Register of }\end{array}$ \\
\hline & PIMRES & Percentage of immigrant residents & 2015 & Inhabitants \\
\hline \multirow[t]{4}{*}{ Tourism supply } & PLHOT & $\begin{array}{l}\text { Hotel beds registered in the } \\
\text { destination }\end{array}$ & 2015 & $\begin{array}{l}\text { IVE Municipal and } \\
\text { District Tourism }\end{array}$ \\
\hline & PLAPA & $\begin{array}{l}\text { Beds in apartments registered in the } \\
\text { destination }\end{array}$ & 2015 & Supply \\
\hline & TOTREGL & $\begin{array}{l}\text { Total regulated beds in the } \\
\text { destination }\end{array}$ & 2015 & \\
\hline & PVPUT & $\begin{array}{l}\text { Percentage of properties potentially } \\
\text { used for tourism (second residence) } \\
\text { in the destination }\end{array}$ & 2011 & $\begin{array}{l}\text { INE Population } \\
\text { and housing } \\
\text { census }\end{array}$ \\
\hline $\begin{array}{l}\text { Economic } \\
\text { situation }\end{array}$ & UNEMP & $\begin{array}{l}\text { Unemployment rate with respect to } \\
\text { the potentially active population }\end{array}$ & 2015 & $\begin{array}{l}\text { Ministry of Labour, } \\
\text { Social Security and } \\
\text { National Statistics } \\
\text { Office }\end{array}$ \\
\hline $\begin{array}{l}\text { Human } \\
\text { pressure }\end{array}$ & PREHUX & $\begin{array}{l}\text { Maximum municipal human } \\
\text { pressure in the destination }\end{array}$ & 2015 & $\begin{array}{l}\text { White paper on } \\
\text { tourism of the } \\
\text { Region of Valencia }\end{array}$ \\
\hline $\begin{array}{l}\text { Composition of } \\
\text { the supply }\end{array}$ & RATIO & $\begin{array}{l}\text { Ratio between } \\
\text { TOTALREGL/PVPUT11 }\end{array}$ & & Own elaboration \\
\hline Province & PROVINCE & $\begin{array}{l}\text { Categorical variable representing } \\
\text { territorial administrative subdivision } \\
\text { (Alicante, Castellón and Valencia) of } \\
\text { the region. }\end{array}$ & & Own elaboration \\
\hline
\end{tabular}

In order to complete the analysis by considering potential confounders, such as the population of the destination or the extent to which the tourism specialisation could be affecting income or unemployment in the two kinds of destination, a regression analysis by ordinary least squares (OLS) has been carried out. According to Angrist \& Pischke (2009:34) "regression estimates provide a valuable baseline for almost all empirical research because regression is tightly linked to the conditional expectation function, and the conditional expectation function provides a natural summary of empirical relationship". All analyses have been conducted using the R statistical language version 3.5.1 (R Core, 2018) and Gretl (Cottrell \& Lucchetti, 2007). This methodology has been intensively used by previous studies on the topic (see e.g. Perles, Ramón, Sevilla \& Moreno, 2016).

\section{Results}

Table 3 shows the descriptive statistics of the variables analysed, both as a whole and broken down according to the type of destination. By examining the table, it can be observed the differentiation 
between the two groups based on the RATIO variable, whose aggregated mean is 0.21 , with 0.38 corresponding to the registered supply group and 0.04 to the non-registered accommodation supply.

Table 3. Descriptive analysis of variables

\begin{tabular}{lllllll} 
& \multicolumn{2}{l}{$\begin{array}{l}\text { All observations } \\
\mathbf{N}=54\end{array}$} & \multicolumn{2}{l}{$\begin{array}{l}\text { Registered group } \\
\mathbf{N}=\mathbf{2 7}\end{array}$} & $\begin{array}{l}\text { Non-registered group } \\
\mathbf{N}=\mathbf{2 7}\end{array}$ \\
\hline Variable & Mean & $\begin{array}{l}\text { Standard } \\
\text { deviation }\end{array}$ & Mean & $\begin{array}{l}\text { Standard } \\
\text { deviation }\end{array}$ & Mean & $\begin{array}{l}\text { Standard } \\
\text { deviation }\end{array}$ \\
\hline INCOME & $\mathbf{1 8 , 0 5 3}$ & $\mathbf{2 , 3 0 0}$ & $\mathbf{1 7 , 6 5 9}$ & $\mathbf{2 , 4 3 7}$ & $\mathbf{1 8 , 4 4 6}$ & $\mathbf{2 , 1 2 8}$ \\
EMPLOYMENT & 5,332 & 5,370 & 5,334 & 5,585 & 5,331 & 5,252 \\
POPU & 20,370 & 20,798 & 19,078 & 18,840 & 21,661 & $\mathbf{2 2 , 8 7 7}$ \\
PIMRES & 0.16 & 0.14 & 0.22 & 0.16 & 0.10 & 0.08 \\
TOTREGL & 6,015 & 11,448 & 10,263 & 15,013 & 1,767 & 2,078 \\
PLHOT & 1,610 & 5,621 & 2,884 & 7,795 & 336 & 522 \\
PLAPA & 3,347 & 5,031 & 5,715 & 6,163 & 978 & 1,395 \\
PVPUT & 30,357 & 40,532 & 25,984 & 24,269 & 34,730 & 52,155 \\
UNEMP & 0.12 & 0.02 & 0.11 & 0.02 & 0.12 & 0.02 \\
PREHUX & 2,026 & 1,858 & 1,690 & 1,567 & 2,362 & 2,086 \\
RATIO & 0.21 & 0.24 & 0.38 & 0.24 & 0.04 & 0.03 \\
\hline
\end{tabular}

Apart from this difference in the variable that defines the classification of the groups, few differences can be observed between them. With respect to the variables of interest, the average disposable income has a higher value in the group where the non-registered accommodation predominates than in the registered accommodation group. The volume of employment, meanwhile, is practically identical in both types of destination. In principle, this implies a counterintuitive result with respect to the findings of the studies reviewed in the introduction of this article.

Table 4 shows the results of the t-test of differences of measures implemented with respect to the disposable income and the employment in destinations. We can observe that there is no significant difference either in the level of income or employment between the two types of destination. Again, this implies a counterintuitive result with respect to the studies reviewed in the introduction of this article.

As already mentioned, in order to correct the effect that potential cofounders may have, Tables 5 to 8 show the results of the linear regressions carried out with income and employment as dependent variables.

Table 5 illustrates how the variables incorporated into the model have a low-medium explanatory power over income $\left(\mathrm{R}_{2}=0.35\right)$. The model diagnosis shows that collinearity is not an issue in the estimated regression, with a maximum variance inflation factor (VIF) of 4.38 for the provincial dummy of Alicante. As it is below the threshold of 10.0 it indicates not collinearity problems. The Ramsey RESET functional specification test suggests that the linear model is adequate ( $\mathrm{p}$-value of F-test ranging from o.11 for the squares to only 0.29 for squares and cubes). 
Table 4. NHST means difference between tourist destinations in the Region of Valencia

\begin{tabular}{|c|c|c|c|c|c|c|}
\hline Variable & $\begin{array}{l}\text { Non- } \\
\text { registered } \\
\text { mean }\end{array}$ & $\begin{array}{l}\text { Registered } \\
\text { mean }\end{array}$ & $\begin{array}{l}\text { Two } \\
\text { sample t- } \\
\text { test }\end{array}$ & p-value & $\begin{array}{l}\text { Theoretical } 95 \% \\
\text { CI for means } \\
\text { difference }\end{array}$ & $\begin{array}{l}\text { Bootstrapped } 95 \% \\
\text { CI for means } \\
\text { difference }\end{array}$ \\
\hline INCOME & 18,446 & 17,659 & 1.264 & 0.21 & $\begin{array}{l}(-492.51, \\
+2,066.88)\end{array}$ & $(-438.45,+1,926.92)$ \\
\hline EMPLOY & 5,331 & 5,334 & -0.00 & 0.99 & $\begin{array}{l}(-3,035.91, \\
3,030.06)\end{array}$ & $\begin{array}{l}(-2,852.88 \\
+2,774.65)\end{array}$ \\
\hline
\end{tabular}

Source: Authors' own elaboration. Note: Non-parametric Wilcoxon rank sum tests also does not reject the null of equality of means in all cases at 95 per cent significance level.

The analysis of the significant coefficients highlights that the average disposable income of the residents (INCOME) is positively related to the size of the destination (POPU) and its building density (PREHUX) and negatively related to the percentage of the residential immigrant population (PINMRES) and the level of unemployment (UNEM). With respect to the variables of interest, it may be observed that the hotel beds existing in the destinations (PLHOT) and the rental property places (PVPUT) are associated to lower levels of income in the destination, as significant negative coefficients are obtained. On the other hand, places in apartments and the provincial dummy variables are not significant. Therefore, it seems that the higher or lower presence of registered accommodation in tourist destinations does not translate into a higher or lower level of the well-being of its residents (measured through the average disposable family income), once the effect of other relevant variables such as the size of the population or the economic situation of the destination has been eliminated. Rather, it seems that, in general, a greater tourism accommodation supply - irrespectively of whether it is registered or not - is associated to lower levels of income in the destinations, which could be explained by other factors that are not included in the model, such as the greater diversification or tourist specialisation in destinations. In this sense, it is possible, for example, for a destination that is predominantly dependent on tourism as main source of income to have lower income levels than a destination that also has other sources of income with higher income levels.

In addition to the limited explanatory power of the estimated model, an analysis of residuals indicates a lack of normality $\left(\chi^{2}=10.99, p\right.$-value $\left.=0.00\right)$. Therefore, in order to avoid possible deficiencies in the inference of the previous results, paired bootstrap confidence intervals have been estimated based on 1,ooo replications for the variables that reflect the accommodation supply (see Table 6). As we can see in the third column, none of the variables are statistically significant - zero forms part of all of the estimated confidence intervals - although if we observe the upper limit of the intervals, an important difference can be seen between the theoretical interval and the bootstrap for the variable that represents the existing hotel places in the destination (PLHOT), which, in this case, would be consistent with a positive effect on the higher disposable incomes as observed for the apartment places and rental property places. In conclusion, the result obtained from applying the bootstrap procedure partly contradicts the result found in the previous paragraph as none of the variables that represent the supply would now contribute to explaining the levels of disposable income in the destinations. While there is a positive effect, it seems that it is more attributable to the hotel places existing in the destination than to any other of the models that may be implemented.

Table 7 reproduces the analysis using the level of employment observed in the destination as a dependent variable. In this case, and contrary to the regression for income, the model for employment shows signs of overfitting ( $\left.\mathrm{R}_{2}=0.96\right)$. The multicollinearity (as the explanatory variables are the same, the results of this diagnosis are also the same as those in the previous regression) and functional 
specification test (F-test ranging from 0.44 for the cubes-only specification to the 0.53 for the squaresonly specification) show no problems in the estimated model.

Table 5. OLS regression of Income level of destinations on explanatory variables

\begin{tabular}{|c|c|c|c|c|}
\hline & Coefficient & Std. Error & t-ratio & p-value \\
\hline const & $24,252.3$ & $2,751.69$ & 8.814 & $<0.0001$ \\
\hline PVPUT & -0.0192 & 0.0091 & -2.093 & 0.0422 \\
\hline POPU & 0.0533 & 0.0224 & 2.378 & 0.0218 \\
\hline PREHUX & 0.3377 & 0.1868 & 1.808 & 0.0775 \\
\hline PINMRES & $-9,021.17$ & $2,634 \cdot 39$ & $-3 \cdot 424$ & 0.0013 \\
\hline UNEM & $-42,653 \cdot 5$ & $20,064 \cdot 9$ & -2.126 & 0.0392 \\
\hline PLHOT & -0.1011 & 0.0417 & -2.421 & 0.0196 \\
\hline PLAPA & 0.0471 & 0.0555 & 0.8489 & 0.4005 \\
\hline VALENCIA & $-729 \cdot 578$ & $957 \cdot 429$ & -0.7620 & 0.4501 \\
\hline CASTELLON & $-1,464.90$ & $1,083 \cdot 58$ & -1.352 & 0.1833 \\
\hline R-squared & 0.3520 & \multicolumn{2}{|c|}{ Adjusted R-squared } & 0.2195 \\
\hline $\mathrm{F}(9,44)$ & 4.0432 & \multicolumn{2}{|c|}{ P-value $(F)$} & 0.0007 \\
\hline Log-likelihood & -482.4036 & \multicolumn{2}{|c|}{ Akaike criterion } & 984.8071 \\
\hline Schwarz criterion & $1,004.697$ & \multicolumn{2}{|c|}{ Hannan-Quinn } & 992.4779 \\
\hline
\end{tabular}

Note: Heteroskedasticity-robust standard errors, variant $\mathrm{HC}_{1}$

Table 6. Theoretical and bootstrapped (pairs) 95\% CI coefficients based on 1,ooo repetitions

\begin{tabular}{lll}
\hline Coefficient & $\begin{array}{l}\text { Theoretical 95\% CI for } \\
\text { coefficients }\end{array}$ & $\begin{array}{l}\text { Bootstrapped 95\% CI for } \\
\text { coefficients }\end{array}$ \\
\hline PLHOT & $(-0.1853,-0.0169)$ & $(-0.1997,1.6311)$ \\
PLAPA & $(-0.0647,0.1591)$ & $(-0.3030,0.1756)$ \\
PVPUT & $(-0.0377,-0.000)$ & $(-0.0588,0.0137)$ \\
\hline
\end{tabular}

An examination of the significant coefficients reveals that, as in the case of income, the size of the destinations (POPU) is associated to a positive effect on the level of employment. In this model, we can also observe, as in the previous case, that the composition of the accommodation supply does affect the dependent variable. Specifically, while the greater presence of hotel supply (PLHOT) is associated to higher levels of employment in the destination, the greater presence of rental accommodation (PVPUT) is associated to lower levels of employment.

As in the previous case, the model suffers from a lack of normality in the residuals $\left(\chi^{2}=7.24, p\right.$ value $=0.02$ ), which, again necessitates a bootstrap analysis of the coefficients of interest (Table 8). As we can see in the last column of the table and contrary to what we can observe in Table 6 , now the negative effect associated to a greater presence of the supply of rental accommodation is clearly confirmed. However, the coefficient associated to the hotel places is not significant. Furthermore, it may be observed that in the upper limit of the intervals there is no longer an important difference between the theoretical interval and the bootstrap for the variable that represents the hotel places existing in the destinations (PLHOT). The conclusions would be slightly different to those of the previous case, with a clearer association of higher levels of employment in destinations with a greater hotel presence and lower levels where there is a greater presence of rental accommodation. 
Table 7. OLS regression of Employment levels of destination on explanatory variables

\begin{tabular}{lrrrr} 
& Coefficient & Std. Error & t-ratio & p-value \\
\hline const & $1,130.45$ & $1,085.14$ & 1.042 & 0.3032 \\
PVPUT & -0.0252 & 0.0063 & -3.948 & 0.0003 \\
POPU & 0.2728 & 0.0145 & 18.71 & $<0.0001$ \\
PREHUX & -0.0406 & 0.0693 & -0.5860 & 0.5608 \\
PINMRES & $-1,231.28$ & $2,256.05$ & -0.5458 & 0.5880 \\
UNEM & $-5,524.87$ & $7,462.84$ & -0.7403 & 0.4630 \\
PLHOT & 0.1635 & 0.0343 & 4.759 & $<0.0001$ \\
PLAPA & 0.0223 & 0.0508 & 0.4396 & 0.6624 \\
VALENCIA & -71.9052 & 957.076 & -0.07513 & 0.9405 \\
CASTELLON & 245.398 & 835.199 & 0.2938 & 0.7703 \\
\hline R-squared & 0.9686 & Adjusted R-squared & 0.9621 \\
F(9, 44) & 419.3284 & P-value(F) & $<0.0001$ \\
Log-likelihood & -446.4496 & Akaike criterion & 912.8991 \\
Schwarz criterion & 932.7890 & Hannan-Quinn & 920.5699 \\
\hline
\end{tabular}

Note: Heteroskedasticity-robust standard errors, variant $\mathrm{HC}_{1}$

Table 8. Theoretical and bootstrapped (pairs) 95\% CI coefficients based on 100 repetitions

\begin{tabular}{lll}
\hline Coefficient & $\begin{array}{l}\text { Theoretical 95\% CI for } \\
\text { coefficients }\end{array}$ & $\begin{array}{l}\text { Bootstrapped 95\% CI for } \\
\text { coefficients }\end{array}$ \\
\hline PLHOT & $(0.0943,0.2328)$ & $(-0.3645,0.2566)$ \\
PLAPA & $(-0.0801,0.1248)$ & $(-0.0972,0.2200)$ \\
PVPUT & $(-0.0381,-0.0123)$ & $(-0.0455,-0.0086)$ \\
\hline
\end{tabular}

In summary, the analysis carried out indicates that, contrary to the findings of the studies mentioned in the introduction, the composition of the accommodation supply, at least in the case of the coastal destinations in the Region of Valencia, hardly affect the income of the residents of the destinations, although a greater impact on the volume of employment of residents can be appreciated in hotel-based destinations.

This result could have transcendental implications for the well-being of the population. As we have seen in the introduction. it should be remembered that, according to Exceltur, there is clear evidence of the greater economic impact of hotel destinations with respect to residential ones. However, with respect to the population, although the hotel destinations may benefit from higher employment, there is no evidence of higher income from the tourism activity. This result may give rise to greater discontent among the resident population with respect to tourists and the economic activity due to an evident lack of distribution of wealth.

\section{Discussion}

With respect to the behaviour of employment in tourist destinations, the results obtained coincide with the findings of Perles-Ribes, Ramón-Rodríguez, Sevilla-Jiménez \& Moreno-Izquierdo (2016) which reveal a decline in the employment performance of the residential destinations during the latest economic crisis. Jolliffe \& Farnsworth (2003) or Santana (2005) reveal that the benefits of inbound tourism and the quality of employment are highly dependent on tourism development and critically analyse the employment conditions in tourism destinations. 
Likewise, with regard to the income generated for residents, the absence of significant differences between destinations confirms the findings of Perles-Ribes, Ramón-Rodríguez, Sevilla-Jiménez \& Moreno-Izquierdo (2018) using the retail supply in the destinations as a proxy for this income. It appears that this absence of differences between the two types of destination, at least in the case of the sun and beach destinations in Spain, could be a robust result.

However, the results obtained differ greatly to the large differences between the two types of destinations suggested by the studies of the main association of tourism firms in Spain (Exceltur). The results obtained in these studies raise new scientific questions of interest. First, leaving aside the legal considerations and the problems that may arise for the market due to a possible presence of unfair competition, it would be necessary to confirm, with alternative methodologies or new data, whether there are indeed differences in the income or added value generated by the two types of accommodation supply (registered versus not registered) as large as those suggested by the Exceltur studies. As highlighted in the introduction section, differences of 11 to 1 in the year 2003 or 5 to 1 in 2015 in favour of registered establishments should be reflected in the income of the residents of the different destinations. However, the different studies carried out do not seem to confirm this reflection.

Difficulties arise when translating the theoretical differences obtained by Exceltur in an abstract contemplation of the activity into observable differences in a defined territorial area of destinations. This is due to the mixed configuration of many of the destinations which have an abundant supply of both types of accommodation establishments and the difficulty in obtaining a precise classification of the destinations (Perles-Ribes, Ivars-Baidal, Ramón-Rodríguez, Such-Devesa, 2019).

Second, if indeed new studies were to confirm such differences, the second question to be raised would refer to the distribution mechanisms of the benefits generated by the tourism industry. Moreover, in what way can this non-translation of the benefits of tourism activity into improvements in the situation of the local population affect the social sustainability of tourist destinations? The literature that examines social sustainability within tourism is scarce. It is mainly focused on the conflict between hosts and guests but does not analyse social sustainability from the perspective of the income distribution generated by tourism in the different development models.

In view of these results, and in a context of growing concern about issues such as over-tourism, the lesson for academics and practitioners would be the need to pay more attention to the mechanisms of distribution of the benefits generated by the tourism activity which is a topic that has received less attention by researchers than those related to the competitiveness of destinations or the quantity of benefits generated by the activity.

\section{Conclusions}

The tourism literature indicates that there are differences in terms of economic activity and the level of employment generated by the different types of tourism implemented in tourism destinations. Specifically, the previous literature points to relevant differences in favour of the registered accommodation supply (hotels and apartments) as opposed to that made up of rental properties.

This article seeks to test, for a group of coastal destinations in the Region of Valencia, whether the different composition of the accommodation supply and the different economic impact indicated by the literature translates into a better well-being of the resident population, measured through available income and the level of employment existing in the destinations. Therefore, after classifying the destinations into two groups - those in which there is a predominance of registered accommodation 
and those where there is a majority of non-registered accommodation - statistical procedures have been used to analyse the existence of significant differences in the levels of family income and employment between the two types of destination.

The results obtained indicate the neutrality of the composition of the accommodation supply on these variables. Neither through exploratory analysis nor through ordinary regression analysis techniques is it possible to obtain significant differences attributable to the composition of accommodation, once the effect of other relevant variables that affect the analysis has been discounted. Only through advanced techniques is it possible to obtain, with the data available for this case, a result that indicates that a destination with a higher presence of hotels can be favourably related to higher volumes of employment. On the contrary, a greater supply of rental accommodation is negatively associated to the level of employment of the destination. Whether this higher or lower level of employment translates into higher levels of disposable income of the residents of the destination is a matter for further discussion.

In conclusion, it seems clear that, at least in the case of the Region of Valencia, the large differences between the different types of accommodation supply do not have any real reflection in the level of well-being of the residents of the destinations. Despite the limitations of this brief study and the difficulties encountered by the researchers in each stage, it opens the door to the possibility of carrying out new studies that seek to generalise the findings of this study to a wider group of regions and countries. They will also analyse in greater depth the mechanisms of distributing the economic activity generated in the destinations and their repercussion on the well-being of the residents in terms of the quality of the employment generated which is one of the true objectives of tourism competitiveness.

\section{References}

Almeida-García, F., Peláez-Fernández, M. Á., Balbuena-Vazquez, A., \& Cortes-Macias, R. (2016). Residents' perceptions of tourism development in Benalmádena (Spain). Tourism Management, 54, 259-274.

Angrist, J.D. \& Pischke, J.S. (2009). Mostly Harmless Econometrics. An Empricist's companion. Princeton University Press. Princeton. New Jersey.

Aref, F. (2011). The effects of tourism on quality of life: A case study of Shiraz, Iran. Life Science Journal, 8(2), 26-30.

Brida, J. G., Riaño, E., Such-Devesa, M. J., \& Zapata-Aguirre, S. (2012). Valoración del turismo de cruceros por parte de la comunidad local: Cartagena de Indias. Scripta Nova. Revista electrónica de Geografía y Ciencias Sociales, 16.

Cardoso, C., \& Silva, M. (2018). Residents' perceptions and attitudes towards future tourism development: A challenge for tourism planners. Worldwide Hospitality and Tourism Themes, 10(6), 688-697.

Cottrell, A \& Lucchetti, R. (2007). Gretl User Manual, http://ricardo.ecn.wfu.edu/pub/gretl/manual/

Dwyer, L. \& Kim, C. (2003). Destination competitiveness: determinants and indicators. Current Issues in Tourism, 6 (5), 369-414.

Exceltur (2005). Impactos sobre el entorno, la economía y el empleo de los distintos modelos de desarrollo turístico del litoral mediterráneo español, Baleares y Canarias. URL:http://www.Exceltur.org/excelo1/contenido/portal/encuentro/Sumario_residencial_completo. pdf. (Accessed 15.12.2018)

Exceltur (2015). Alojamiento turístico en viviendas de alquiler. Impactos y retos asociados. Impactos sociales y económicos sobre los destinos españoles derivados del exponencial aumento del alquiler de viviendas turísticas de corta duración, impulsado por los nuevos modelos y canales de comercialización $P_{2} P$. URL: https://www.Exceltur.org/wp-content/uploads/2015/o6/Alojamiento-turístico-en- 
viviendas-de-alquiler-Impactos-y-retos-asociados.-Informe-completo.-Exceltur.pdf

(Accessed 15.12.2018)

Exceltur (2018a). Comunitat Valenciana, Impactur 2017. Estudio del Impacto Económico del Turismo sobre la Economía y el Empleo. URL: https://www.exceltur.org/wpcontent/uploads/2018/12/IMPACTUR-Comunidad-Valenciana-2017.pdf (Accessed 15.12.2018)

Exceltur (2018b). Monitur. Monitor de competitividad turística relativa de las comunidades autónomas españolas. URL: https://www.exceltur.org/monitur/ (Accessed 15.12.2018)

Filep S., \& Deery M. (2010). Towards a Picture of Tourists' Happiness. Tourism Analysis, 15 (4), 399-410.

Garcia, C., \& Servera, J. (2003). Impacts of tourism development on water demand and beach degradation on the island of Mallorca (Spain). Geografiska Annaler: Series A, Physical Geography: $85(3-4), 287-300$.

Gartner, W.C. (1987). Environmental impacts of recreational home development. Annals of Tourism Research, 14, 38-57.

Hall, C.M. (2015). Second homes planning, policy and governance. Journal of Policy Research in Tourism, Leisure and Events, 7 (1), 1-14.

Herrero, C., Villar, A., \& Soler, A. (2018). Las facetas del bienestar: una aproximación multidimensional a la calidad de vida en España y sus comunidades autónomas (2006-2015). Fundación BBVA. Bilbao.

INE Instituto Nacional de Estadística de España (2017a). Frontur. Movimiento turístico en Fronteras. URL:http://www.ine.es/dyngs/INEbase/es/operacion.htm?c=Estadistica_C\&cid=1254736176996\&m enu=ultiDatos\&idp=1254735576863 (Accessed 15.12.2018)

INE Instituto Nacional de Estadística de España (2017b). Familitur. Encuesta de turismo a residentes. URL:http://www.ine.es/dyngs/INEbase/es/operacion.htm?c=Estadistica_C\&cid=125473617699o\&m enu=ultiDatos\&idp=1254735576863 (Accessed 15.12. 2018)

INE Instituto Nacional de Estadística de España (2018a). Encuesta de Condiciones de Vida. Satisfacción global con la vida.

URL:http://www.ine.es/ss/Satellite?L=es_ES\&c=INESeccion_C\&cid=1259944627813\&p=1254735110672\& pagename=ProductosYServicios\%2FPYSLayout\&paramı=PYSDetalleFichaIndicador\&param3=12599 37499084 (Accessed 07.6. 2019).

INE Instituto Nacional de Estadística de España (2018b). Contabilidad regional de España. https://www.ine.es/dyngs/INEbase/es/operacion.htm?c=Estadistica_C\&cid=1254736167628\&menu= resultados\&idp $=1254735576581$ (Accessed 07.6. 2019)

Ivars-Baidal, J. A., I. Rodríguez-Sánchez \& Vera-Rebollo, J.F. (2013). The evolution of mass tourism destinations: New approaches beyond deterministic models in Benidorm (Spain). Tourism Management, 34, 184-195.

Liang, Z. X., \& Hui, T. K. (2016). Residents' quality of life and attitudes toward tourism development in China. Tourism Management, 57, 56-67.

Mazón, T. (2006a). Inquiring into Residential Tourism: The Costa Blanca Case. Tourism and Hospitality Planning E Development, 3 (2), 90-97.

Moreno-Izquierdo, L., J. F., Ramón-Rodríguez, A. B., Such-Devesa, M. J., \& Perles-Ribes, J. F. (2019): Tourist environment and online reputation as a generator of added value in the sharing economy: The case of Airbnb in urban and sun- and-beach holiday destinations. Journal of Destination Marketing and Management, 11, 53-66.

Modica, P. \& Uysal, M. (2016). Island Tourism: Sustainability, Competitiveness, and Quality- of-Life. CABI Series in Tourism Management Research.

Morote, F.A., Saurí, D., \& Hernández, M. (2016). Residential Tourism, Swimming Pools, and Water Demand in the Western Mediterranean. The Professional Geographer, 69(1), 1-11.

Nawijn, J., \& Mitas, O. (2012). Resident attitudes to tourism and their effect on subjective well-being: The case of Palma de Mallorca. Journal of Travel Research, 51(5), 531-541. 
Obrador, P. (2017). The end of sustainability? A note on the changing politics of mass tourism in the Balearic Islands. Journal of Policy Research in Tourism, Leisure and Events, 9(2), 205-208.

Perles-Ribes, J., Ramón-Rodríguez, A. \& Sevilla-Jiménez, M. (2011). Determinants of the competitive advantage of residential tourism destinations in Spain. Tourism Economics, 17(2), 373-403

Perles-Ribes, J., Ramón-Rodríguez, A., Sevilla-Jiménez, M. \& Moreno-Izquierdo, L. (2016). Unemployment effects of economic crises on hotel and residential tourism destinations: The case of Spain. Tourism Management, 54 (C), 356-368.

Perles-Ribes, J.F, Ramón Rodríguez, A.B, Sevilla Jiménez, M. \& Moreno-Izquierdo, L. (2018). Differences in the economic performance of hotel based and residential tourist destinations measured by their retail activity. Evidence from Spain. Current Issues in Tourism, 21(18), 2076-2107

Perles-Ribes, J. F., Ramón-Rodríguez, A. B., Ivars-Baidal, J., \& Such-Devesa, M. J. (2018). The use of private vehicles in residential and holiday tourism destinations: the case of Spain. Current Issues in Tourism, 1-20.

Perles-Ribes, J.F., Ivars-Baidal, J., Ramón-Rodríguez, A.B. \& Vera-Rebollo, J.F. (2019). The typological classification of tourist destinations: The region of Valencia, a case study. Tourism Economics, https://doi.org/10.1177/1354816619838413

Postma, A., \& Schmuecker, D. (2017). Understanding and overcoming negative impacts of tourism in city destinations: conceptual model and strategic framework. Journal of Tourism Futures, 3(2), 144156.

R Core Team (2018). R: A language and environment for statistical computing. $R$ Foundation for Statistical Computing, Vienna, Austria. URL http://www.R-project.org/.

Ritchie, J.B., \& Crouch, G.I. (2003). The competitive destination: A sustainable tourism perspective. Wallingford: Cabi.

Sirakaya, E., Teye, V., \& Sönmez, S. (2002). Understanding residents' support for tourism development in the central region of Ghana. Journal of Travel Research, 41(1), 57-67.

Spence, A. M., Hazard, H. A., \& Kennedy, J.F. (1988). International competitiveness. The International Executive, 30(1), 32-34.

Vera, J. F. \& Ivars, J. A. (2003). Measuring sustainability in a mass tourist destination: pressures, perceptions and policy responses in Torrevieja, Spain. Journal of Sustainable Tourism, 11(2-3), 181203.

Received: 14/04/2019

Accepted: 06/07/2019

Coordinating editor: Stanislav Ivanov 